\title{
Effects of Cassia abbreviata extract and stocking density on growth performance, oxidative stress and liver function of indigenous chickens
}

\author{
Martha C. Jobe ${ }^{1} \cdot$ Cyprial N. Ncobela ${ }^{1} \cdot$ Nokuthula W. Kunene $^{1} \cdot$ Andrew R. Opoku $^{1}$ \\ Received: 18 February 2019 / Accepted: 11 June 2019 / Published online: 21 June 2019 \\ (C) The Author(s) 2019
}

\begin{abstract}
The objective of the study was to investigate the effect of stocking density and extract from Cassia abbreviata stem bark on growth performance, oxidative stress and liver function of indigenous chickens. A total of 420 1-day-old female Ovambo chicks with initial body weight of $0.32 \pm 0.036 \mathrm{~kg}$ (mean $\pm \mathrm{SD}$ ) were used in the study. Birds, which were cooped in stocking densities consisting 5, 10 and 20 birds $/ \mathrm{m}^{2}$, were orally administered with $0,50,200$ and $500 \mathrm{mg} / \mathrm{kg}$ of extract from $C$. abbreviata stem bark. Each stocking density per dosage level of extract was repeated three times. Average feed intake was lower $(P<0.05)$ in birds housed at 20 birds $/ \mathrm{m}^{2}$. There was a low $(P<0.05)$ average daily gain in birds housed at 20 birds $/ \mathrm{m}^{2}$. Malondialdehyde was higher $(P<0.05)$ in 20 birds $/ \mathrm{m}^{2}$. Average daily gain was high $(P<0.05)$ in birds administered with 0 and $50 \mathrm{mg} / \mathrm{kg}$ of $C$. abbreviata stem bark extract. Birds administered with 0 and $50 \mathrm{mg} / \mathrm{kg}$ of $C$. abbreviata stem bark extract had a higher $(P<0.05)$ gain to feed ratio. Birds dosed with 500 and $200 \mathrm{mg} / \mathrm{kg}$ had high $(P<0.05)$ superoxide dismutase activity. Birds administered with $500 \mathrm{mg} / \mathrm{kg}$ of $C$. abbreviata stem bark extract had the lowest $(P<0.05)$ malondialdehyde. A $500 \mathrm{mg} / \mathrm{kg}$ of stem bark extract from $C$. abbreviata resulted to higher $(P<0.05)$ activities of aspartate transaminase and alanine transaminase. There was a significant $(P<0.05)$ interaction between the stocking density and $C$. abbreviata extract on catalase activity. High stocking density of $20 \mathrm{birds} / \mathrm{m}^{2}$ reduced growth performance and induced stress in indigenous chickens. High dosage of level $500 \mathrm{mg} / \mathrm{kg}$ of stem bark extract of $C$. abbreviata reduced oxidative stress while depressing growth performance and causing hepatotoxicity in birds. There is a need to precisely determine the maximum dosage level of C. abbreviata extract to improve growth performance and reduce oxidative stress and hepatotoxicity in indigenous chickens in high stocking density.
\end{abstract}

Keywords Average daily gain · Liver enzymes $\cdot$ Plant extract $\cdot$ Stocking density $\cdot$ Superoxide dismutase

\section{Introduction}

The commercial value of indigenous chickens has been gaining attention due to their potential to contribute to economic well-being and national food security (Ncobela and Chimonyo, 2015). This is driven by, among others, exponential increase in human population and consumer choices and preferences. Indigenous chickens are preferred due to tastier meat and their propensity to deposit lesser fat than exotic

Cyprial N. Ncobela

ndumison50@gmail.com; NcobelaC@unizulu.ac.za

1 Faculty of Science and Agriculture, University of Zululand, KwaDlangezwa 3886, South Africa chickens (Gwala, 2014). Indigenous chickens dually provide nutritious meat and eggs (Odunitan-Wayas et al., 2016). However, the stocking density standards for indigenous chickens kept under intensive production systems are unknown. This makes it difficult to intensity their production performance without deterring their wellness. Farmers rely on personal experience in determining the space allowances and use stocking density standards for broilers as a reference point (Tong et al., 2012). This is inappropriate and may lead ethical and welfare concerns. Therefore, there is a need to determine the optimum-stocking density for indigenous chickens kept intensive production system.

Estevez (2007) defined stocking density as number of birds or the total live weight of birds per unit area. For commercial chicken strains, Madilindi et al. (2018) suggested that a stocking density of $35-40 \mathrm{~kg} \mathrm{BW} / \mathrm{m}^{2}$ is suitable for broilers in 42 - 
day production cycle grown in tropical and subtropical environments. Indigenous chickens being hardy, small-framed and slow-growers should in principle be kept at higher stocking densities. However, Dawkins (2018) argued that it is vital to be precise about the space required by birds to perform specific behavioural activities that either can effect health or be important to the birds themselves. In light of this, the temperament of indigenous chickens such as Ovambo breed, which has not been properly documented, could dictate that they need greater space allowances. This highlights the need to determine stocking density standards for indigenous chickens without compromising their well-being.

High stocking density reduces feed intake and growth performance and negatively affects health status (Goo et al., 2018). Stress, as a result of overcrowding, results to metabolic disturbances that cause excessive production of oxygen-derived biological free radicals known as reactive oxygen species that leads to oxidative damage of biomolecules such as lipids (Droge, 2002; Yun-Zhong et al., 2002). The damage of lipids (also known as lipid peroxidation) happens when free radicals abstract electrons from unsaturated fatty acids. Simsek et al. (2009) defined lipid peroxidation, an indicative of stress, as an autocatalytic mechanism leading to oxidative destruction of cellular membrane. Authors further reported that crowding enhances malondialdehyde (MDA), a main final product of lipid peroxidation, in broilers. Such information is also relevant to indigenous chickens, particularly aggressive breed such as Ovambo chickens that were known to be hardy and less stresssensitive. Depending on the intensity of stress, enzymatic antioxidants such as catalase (CAT) and superoxide dismutase (SOD) are involved in the mechanism to protect cells from oxidative stress (Lin et al., 2004). Aspartate aminotransferase (AST) and alanine aminotransferase (ALT) activities are indicators of hepatic health status such as possibility of cytolysis.

To simultaneously improve wellness and profit of indigenous chicken production, there is a need to valorise antioxidant-rich medicinal plants in birds kept under high stocking densities.

Various plant extracts have shown potential to reduce oxidative stress (Surai, 2016). The use of medical plants such as Cassia abbreviata to mitigate oxidative stress and toxicity of the liver while enhancing growth performance needs exploration. Cassia abbreviata is a small- to medium-sized-branched umbrella-shaped deciduous tree with distinctive cylindrically shaped fruits (Sobeh et al., 2018). This perennial tree belongs to the family of Caesalpiniaceae. It is widespread in tropical and subtropical regions such as Gabon, Swaziland, Kenya, Tanzania, South Africa, Botswana and Zimbabwe (Mongalo and Mafoko, 2013). Cassia abbreviata possesses anthocyanins, anthranoids, anthraquinones, polyphenols and tannins (Mongalo and Mafoko, 2013). These phytochemicals have the antioxidant effect and may have a direct bearing on wellness of birds. In our preliminary study, in vitro analyses showed that stem bark from $C$. abbreviata has the ability scavenge synthetic radicals such as 2,2-diphenyl-1-picrylhydrozyl and 2,2'-azinobis (3-ethylbenzothiazoline-6-sulphonic acid) and biological radicals such as superoxide anion, nitric oxide and hydroxyl radicals. The role of $C$. abbreviata extract as an antioxidant source in indigenous chickens kept in different docking densities is, to our best knowledge, reported for the first time. The objective of the study was, therefore, to determine the effect of stocking density and stem bark extract from C. abbreviata on growth performance, oxidative stress and liver function of indigenous chickens. It was hypothesised that dosage levels of C. abbreviata extract counteracts poor growth performance, oxidative stress and hepatotoxicity caused by increasing stocking density.

\section{Methods}

\section{Study site}

The study was conducted at the University of Zululand farm, situated in the University premises at Empangeni, in the Northern KwaZulu-Natal, South Africa. The farm lies at $28.8415^{\circ} \mathrm{S}$ and $31.8263^{\circ} \mathrm{E}$. The ethical committee of the University of Zululand approved the use and care of chickens (UZREC 171110-030 PGM 2014/124).

\section{Collection, extraction and phytochemical screening of Cassia abbreviata stem bark}

Cassia abbreviata trees and their stem barks were identified and freshly harvested at Biaba, which is located in the Limpopo Province, South Africa, and transported to the Department of Botany, University of Zululand. Stem barks were samples from different Cassia abbreviata tress. A voucher specimen (Ramulodi and Jobe MC/01Unizul) was kept in the Herbarium in the Botany Department. Stem barks were eventually chopped, air-dried at room temperature and grounded to powder (pass through a 2-mm sieve). The stem bark powder was extracted using maceration method. Briefly, $200 \mathrm{~g}$ of stem bark powder sample was macerated with methanol on an orbital shaker machine at $157 \mathrm{rpm}$ for $24 \mathrm{~h}$, at room temperature. The ratio of the stem bark to solvent was 1:5. The extract was filtered using Whatman filter paper. Qualitative tests were done for saponins, alkaloids, phenols, terpenoids, tannins and flavonoids for the stem bark using methods described by Harbone (1973). Phytochemicals present in the plant were determined with precipitates formation and colour changes upon the corresponding tests present (Mosa et al.,2012). Phytochemical screening of the stem bark methanol extract of C. abbreviata revealed presence of terpenoids, alkaloids, saponins, tannins and flavonoids. Quantitative tests for total phenolic content and total flavonoid content were 
performed according to Kahkonen et al. (1999) and Ordonez et al. (2006), respectively. Cassia abbreviata stem bark extract contained $3.82 \mathrm{mg} / \mathrm{g}$ of total polyphenolic content and $2.75 \mathrm{mg} / \mathrm{g}$ of total flavonoid content.

\section{Bird management and experimental design}

A total of 420 1-day-old female Ovambo chicks, with initial weight of $0.32 \pm 0.036$ (mean \pm SD), were used in the study. Female chicks were used to avoid sexual effect variation. Chicks were hatched after incubating the eggs for 21 days in the University of Zululand poultry unit. Chicks were vaccinated against Newcastle and Gumboro diseases and were reared in the brooder house. Forty chicks were kept in each pen within the brooder. The temperature was maintained at $32{ }^{\circ} \mathrm{C}$ during the 7 days and then gradually decreased by $3{ }^{\circ} \mathrm{C}$ until a basal temperature of $22{ }^{\circ} \mathrm{C}$ was reached. A standard commercial broiler starter was given to the chickens from day 1 to day 42. From day 43 to 49 , birds were moved to the floor pens with sawdust bedding within the house. Birds were given 7 days (day 43 to 49 ) to adapt to a standard grower diet before data collection commenced. The data collection began from day 50 to day 96 . The starter and grower feed were bought from Meadow Feeds ${ }^{\circledR}$, feed company located in Pietermaritzburg, South Africa. There are no feeding standards and requirements available specifically for Ovambo breed. Therefore, a standard diet from the Meadow feeds ${ }^{\circledR}$ for growing broiler chickens was used. Diet contained $880 \mathrm{~g} / \mathrm{kg}$ dry matter, $160 \mathrm{~g} / \mathrm{kg}$ DM protein, $25 \mathrm{~g} / \mathrm{kg}$ DM fat, $50 \mathrm{~g} / \mathrm{kg}$ fibre, $6 \mathrm{~g} / \mathrm{kg}$ DM calcium, $5 \mathrm{~g} / \mathrm{kg}$ DM phosphorous

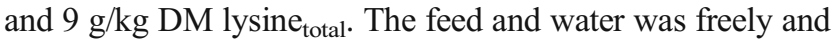
continuously provided using a tube feeders and nipple drinkers, respectively. Birds were grouped into three stocking densities, which consist of low $\left(5 \mathrm{birds} / \mathrm{m}^{2}\right)$, medium (10 birds $\left./ \mathrm{m}^{2}\right)$ and high $\left(20 \mathrm{birds} / \mathrm{m}^{2}\right)$. Grouping of birds was done on day 43 , a day when they were introduced to standard grower diet. Birds, in each stocking density, were orally administered with solution containing different dosages namely 0,50 , 200 and $500 \mathrm{ml} / \mathrm{kg}$ of stem bark extract from C. abbreviata. Each stocking density per dosage of C. abbreviata was repeated three times. A randomized factorial design was used in the study. The dosing was done once a day at 8:00 in the morning. The administration of $C$. abbreviata was performed using a gavage crop needle-feeding syringe.

\section{Measurement of growth performance}

Feed intake and body weights were measured weekly in the morning. Weekly feed intake was determined by weighing the feed out and feed in per week. Average daily feed intake (ADFI) for each week was calculated by dividing weekly feed intake by seven. Average daily gain (ADG) was determined by dividing the difference between body weight at the beginning and the end of each week by seven. The feed to gain ratio (F:G) was determined by diving ADFI by ADG.

\section{Blood analyses}

The blood samples were collected in the wing vein at the last day of the experiment using 23 -gauge needle and syringe. For blood collection, six birds ( 2 birds in each replicate) were sampled from 5 birds $/ \mathrm{m}^{2}, 12$ birds (4 birds in each replicate) from 10 birds $/ \mathrm{m}^{2}$ ) and 15 birds (5 birds from each replicate) from high stocking density of $20 \mathrm{birds} / \mathrm{m}^{2}$. Collected blood samples coagulated at $25^{\circ} \mathrm{C}$ temperature and were centrifuged for $10 \mathrm{~min}$ at $1000 \times \mathrm{g}$ immediately after collection. Serum was extracted and transferred into polypropylene tubes and kept at $-20{ }^{\circ} \mathrm{C}$ for preservation pending analyses. The antioxidant activities such as SOD and CAT were analysed using their respective commercial essay kits. Lipid peroxidation was also estimated based on MDA content using assay kit. The assay kits were obtained from Sigma-Aldrich ${ }^{\circledR}$. The AST and ALT were analysed using the ultraviolet method (Bergmeyer et al., 1986).

\section{Histopathology analyses}

After blood collection, two chickens from each group were humanely slaughtered following the abattoir protocols to collect the liver samples for histopathology analyses. Liver samples were fixed immediately after collection into $10 \%$ neutral formalin prior to preparation and analysis. The histopathology analysis was performed at the Veterinary Diagnostic Laboratory, Pietermaritzburg, South Africa. The method used allowed for unbiased description of the histological lesions which may be present or absent in the samples.

\section{Statistical analysis}

Data were analysed using the statistical package for social sciences SPSS (SPSS, 2012). Effect of stocking and stem bark extract from C. abbreviata was determined using multivariate analysis of variance (MANOVA). Means were separated using Student-Newman-Keuls (post hoc). The values were considered significant when the probability is less 0.05 .

The general linear model used was: $Y=\mu+P_{\mathrm{i}}+W_{\mathrm{j}}+(P \times$ $W)_{\mathrm{ij}}+E_{\mathrm{ijk}}$.

Where $Y_{\mathrm{ijk}}$ is the response variable (growth performance, oxidative stress and liver function); $\mu$ is the overall mean common to all observations; $P_{\mathrm{i}}$ is the effect of stocking density; $W_{\mathrm{i}}$ is the effect of dosage of C. abbreviata; $(P \times \mathrm{W})_{\mathrm{ij}}$ is the interaction between the stocking density and dosage of C. abbreviata; $E_{\mathrm{ijk}}$ is the residual error. 


\section{Results}

\section{Effect of stocking density on growth performance, oxidative stress and liver enzymes}

Average daily feed intake and average daily gain differed with stocking density $(P<0.05)$ (Table 1$)$. Average daily feed intake was low $(P<0.05)$ in birds raised in stocking density of $20 \mathrm{birds} / \mathrm{m}^{2}$ and high in birds kept in stocking density of 5 birds $/ \mathrm{m}^{2}$. Average daily gain was low $(P<0.05)$ in birds cooped in 20 birds $/ \mathrm{m}^{2}$ whereas it was high in 5 birds $/ \mathrm{m}^{2}$. Gain to feed ratio was not affected $(P>0.05)$ by stocking density. Stocking density did not $(P>0.05)$ have an impact on the activity of SOD. Malondialdehyde was higher $(P<$ $0.05)$ in $20 \mathrm{birds} / \mathrm{m}^{2}$. Stocking density did not affect $(P<$ $0.05)$ CAT activity. Stocking density did not influence $(P>$ 0.05 ) activity of ALT and AST.

\section{Effect of Cassia abbreviata extract on growth performance, oxidative stress and liver enzymes}

Increasing dosage level of $C$. abbreviata did not affect $(P<$ 0.05 ) average daily feed intake (Table 2 ). Average daily gain varied $(P<0.05)$ with dosage of $C$. abbreviata extract. Average daily gain was high $(P<0.05)$ in birds administered with 0 and $50 \mathrm{mg} / \mathrm{kg}$ of C. abbreviata stem bark extract. Gain to feed ratio differed $(P<0.05)$ with dosage of $C$. abbreviata extract. Birds administered with 0 and $50 \mathrm{mg} / \mathrm{kg}$ of $C$. abbreviata extract had higher gain to feed ratio. The dosage of $C$. abbreviata extract influenced $(P<0.05)$ SOD activity. Birds, which were administered with $500 \mathrm{mg} / \mathrm{kg}$, had higher $(P<0.05)$ SOD activity. Dosage of $C$. abbreviata extract affected $(P<0.05)$ levels of
MDA. Birds that received $500 \mathrm{mg} / \mathrm{kg}$ had the lowest MDA whereas those that had a dose of $0 \mathrm{mg} / \mathrm{kg}$ had the highest MDA levels. The activity of CAT was not affected by dosage level of stem bark extract from $C$. abbreviata. The activity of AST varied $(P<0.05)$ with dosage level of $C$. abbreviata extract. A dosage levels of 200 and $500 \mathrm{mg} / \mathrm{kg}$ of C. abbreviata extract had the highest $(P<0.05)$ AST activity. Birds that did not receive $C$. abbreviata extract had the lowest $(P<0.05)$ activity of ALT.

\section{Interaction between stocking density and C. abbreviata extract on growth performance, oxidative stress and liver enzymes}

There were no significant interactions $(P>0.05)$ between stocking density and dosage level of $C$. abbreviata extract on growth performance (Fig. 1). There was a significant interaction $(P<0.05)$ between the stocking density and dosage of C. abbreviata extract on CAT activity. A dosage of $500 \mathrm{mg} / \mathrm{kg}$ of C. abbreviata extract resulted to lower CAT in stocking density of 5 birds $/ \mathrm{m}^{2}$ and higher CAT activity in stocking density of $20 \mathrm{birds} / \mathrm{m}^{2}$.

\section{Histopathological changes of liver of chickens administered with levels of $C$. abbreviata stem bark extract}

There were no observed histopathological changes at different stocking densities of indigenous chickens. Nonetheless, marked changes were noted in the livers of chickens given different dosages of the C. abbreviata stem bark extract (Fig. 2). A normal liver sample of the group of chickens that

Table 1 Effect of stocking density on growth performance, oxidative stress and liver function of indigenous chickens

\begin{tabular}{lllll} 
Stocking density $\left(\right.$ birds $\left./ \mathrm{m}^{2}\right)$ & & & Significance \\
\hline 5 & 10 & 20 & SEM
\end{tabular}

Growth performance

\begin{tabular}{|c|c|c|c|c|c|}
\hline ADFI (kg) & $0.14^{\mathrm{a}}$ & $0.10^{\mathrm{b}}$ & $0.04^{\mathrm{c}}$ & 0.02 & $* *$ \\
\hline $\mathrm{ADG}(\mathrm{kg})$ & $0.04^{\mathrm{a}}$ & $0.03^{\mathrm{ab}}$ & $0.01^{\mathrm{c}}$ & 0.00 & $* *$ \\
\hline G:F ratio & 0.28 & 0.30 & 0.27 & 0.09 & NS \\
\hline
\end{tabular}

Oxidative stress

$\begin{array}{rccccc}\text { SOD }(\%) & 62.2 & 54.1 & 53.8 & 1.02 & \text { NS } \\ \text { MDA }(\%) & 16.5^{\mathrm{b}} & 16.0^{\mathrm{b}} & 19.1^{\mathrm{a}} & 0.09 & * \\ \text { les } / \mathrm{min} / \mathrm{ml}) & 0.07 & 0.07 & 0.06 & 0.03 & \text { NS }\end{array}$

CAT $(\mu \mathrm{moles} / \mathrm{min} / \mathrm{ml})$

0.07

3.82

AST (units/L)

3.85

$\begin{array}{lll}34.3 & 33.9 & 34.1\end{array}$

3.89
34.1

0.18

3.48

NS

$*$
$*$
*
$\mathrm{S}$
$\mathrm{N}$
$\mathrm{N}$

Values in the same row with different superscript letters differ $(P<0.05) * P<0.05$, ** $P<0.01, N S$ not significant $(P>0.05)$

$A D F I$ average daily feed intake, $A D G$ average daily gain, $G: F$ gain to feed, $S O D$ superoxide dismutase, $M D A$ Malondialdehyde, $C A T$ catalase, $A S T$ Aspartate aminotransferase, $A L T$ alanine aminotransferase 
Table 2 Effect of dosage level on Cassia abbreviata extract on growth performance, oxidative stress and liver function of indigenous chickens

Cassia abbreviata extract $(\mathrm{mg} / \mathrm{kg})$

Significance

0

50

200

500

SEM

Growth performance

$\begin{array}{rlllllr}\text { ADFI }(\mathrm{kg}) & 0.08 & 0.08 & 0.07 & 0.08 & 0.001 & \text { NS } \\ \text { ADG }(\mathrm{kg}) & 0.03^{\mathrm{a}} & 0.03^{\mathrm{a}} & 0.01^{\mathrm{b}} & 0.01^{\mathrm{b}} & 0.001 & * \\ \text { G:F ratio } & 0.38^{\mathrm{b}} & 0.38^{\mathrm{b}} & 0.14^{\mathrm{a}} & 0.13^{\mathrm{a}} & 0.014 & *\end{array}$

Oxidative stress

\begin{tabular}{|c|c|c|c|c|c|c|}
\hline SOD (\%) & $45.2^{\mathrm{C}}$ & $51.6^{\mathrm{b}}$ & $60.3^{\mathrm{ab}}$ & $69.7^{\mathrm{a}}$ & 1.68 & $* *$ \\
\hline MDA (\%) & $32.5^{\mathrm{a}}$ & $18.2^{\mathrm{b}}$ & $11.0^{\mathrm{c}}$ & $7.03^{\mathrm{d}}$ & 0.36 & $* *$ \\
\hline les/min/ml) & 0.10 & 0.09 & 0.08 & 0.11 & 0.02 & NS \\
\hline ST (units/L) & $2.59^{\mathrm{b}}$ & $2.89^{\mathrm{b}}$ & $3.05^{\mathrm{ab}}$ & $3.30^{\mathrm{a}}$ & 0.11 & * \\
\hline $\mathrm{T}$ (units /L) & $11.9^{\mathrm{b}}$ & $39.4^{\mathrm{a}}$ & $42.3^{\mathrm{a}}$ & $44.3^{\mathrm{a}}$ & 1.87 & * \\
\hline
\end{tabular}

Values in the same row with different superscript letters differ $(P<0.05) * P<0.05, * * P<0.01, N S$ not significant $(P>0.05)$

$A D F I$ average daily feed intake, $A D G$ average daily gain, $G: F$ gain to feed, $S O D$ superoxide dismutase, $M D A$ Malondialdehyde, $C A T$ catalase, $A S T$ Aspartate aminotransferase, $A L T$ alanine aminotransferase

did not receive a dose $(0 \mathrm{mg} / \mathrm{kg})$ of $C$. abbreviata extract had branching and anatomical cords radiating from the central vein with vesicular nuclei. Hepatocytes were within the normal limits with multifocal lymphocytic hepatitis and triaditis (Fig. 2: Image I). After administration of C. abbreviata extract with $50 \mathrm{mg} / \mathrm{kg}$, liver exhibited mild congestions in the lymphocytic hepatitis. There were also necrotic changes observed in the liver. Hydropic swellings of hepatocytes were observed (Fig. 2: Image II). Similar observations were also noted in birds dosed with $200 \mathrm{mg} / \mathrm{kg}$ (Fig. 2: Image III). Following administration of $500 \mathrm{mg} / \mathrm{kg}$ of C. abbreviata stem bark extract, liver sample had few small focal areas of necropurulent hepatitis with scant accompanying epithelioid cells, macrophages and lymphocytes were observed (Fig. 2: Image IV).

\section{Discussion}

The development of indigenous chicken as a commercial enterprise is contingent upon several factors including demand for welfare ethics. Crowding of chicken per given space is financial viable but compromises wellness (Dawkins, 2018). Therefore, it is crucial to determine stocking density standards for indigenous chicken to ensure its effective and welfarefriendly production. Findings that high stocking density (20 birds $/ \mathrm{m}^{2}$ ) reduced ADFI correspond well with those of Tong et al. (2012) who reported a decrease in feed intake as stocking density increased in local chicken breed. In two separate studies, Simitzis et al. (2012) and Madilindi et al. (2018) reported a decrease in feed intake in birds kept in higher stocking density.
Fig. 1 Interaction between levels of concentration of $C$. abbreviata extract and stocking density on catalase activity in indigenous chickens

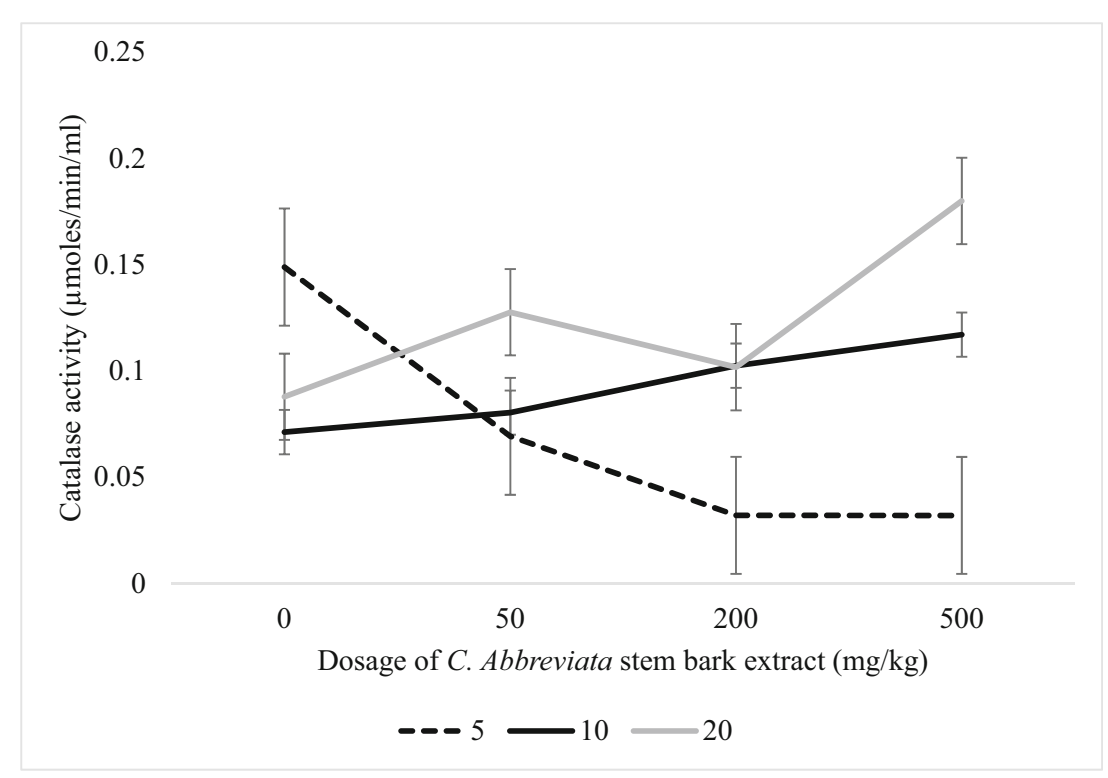


Fig. 2 Photomicrographs represent cross-sections of histopathological changes of the liver of indigenous chickens administered with different dosages of C. abbreviata stem bark extract

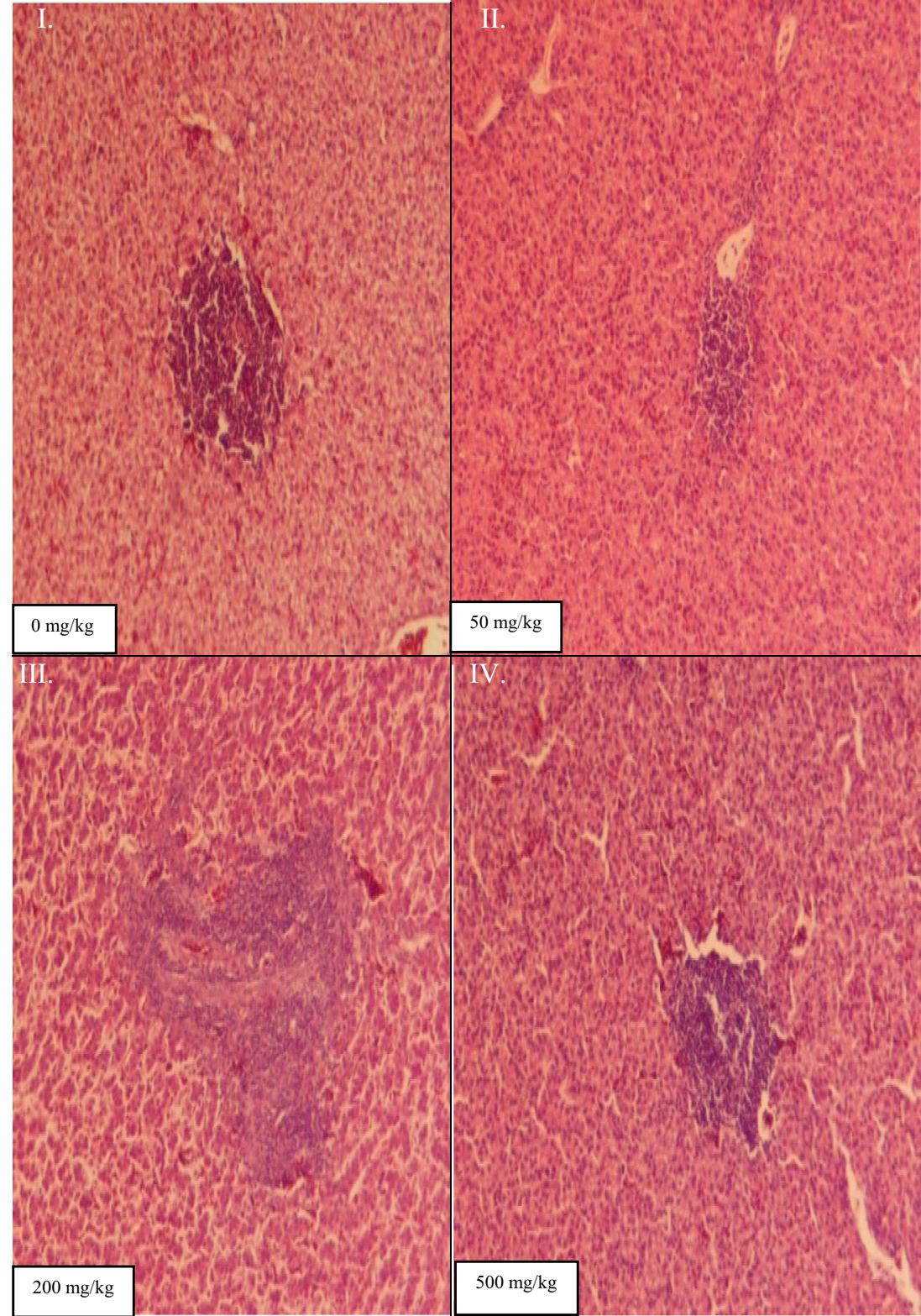

Several studies have confirmed a decrease in feed intake as a result of overcrowding (Moreira et al., 2004; Thomas et al., 2004; Goo et al., 2018). Cengiz et al. (2015) reported that high stocking density distracts the mobility of birds in a given space. Thus, overcrowded birds battle to access feeders and drinkers. This may promote aggressive behaviour on birds such as pecking and threatening and reduce feeding behaviour. Male Ovambo chickens are normally aggressive (Joubert, 1996), which highlights the potential sensitivity to high stocking density. Increase in body temperature as a result of high stocking density may negatively influence feed intake. A higher ADG in stocking density of $5 \mathrm{birds} / \mathrm{m}^{2}$ is similar to report by Mtileni et al. (2007) who cited that birds in lower stocking density were heavier than birds raised in high stocking density. These findings tantamount to the report by Tong et al. (2012) who reported a decline in ADG as stocking density rose in indigenous chickens. Dozier III et al. (2006) highlighted that increasing stocking density beyond $35 \mathrm{~kg}$ of $\mathrm{BW} / \mathrm{m}^{2}$ suppressed final BW by $6 \%$. Higher MDA levels in birds raised in high stocking density $\left(20 \mathrm{birds} / \mathrm{m}^{2}\right)$ agrees with findings of Simsek et al. (2009) who indicated that crowding enhanced oxidative destruction and caused MDA generation.

A growing body of evidence shows that most of stresses in poultry production, at the cellular level, are associated with oxidative stress (Surai, 2016). The use of extracts from medicinal plants in poultry to combat stress as a result of crowding is, therefore, vital and requires exploration. A lower ADG in birds administered with 200 and $500 \mathrm{mg} / \mathrm{kg}$ of stem bark extract of C. abbreviata compared with 0 and $50 \mathrm{ml} / \mathrm{kg} \mathrm{BW}$ suggests that dosing birds with high concentration of $C$. abbreviata 
negatively affected growth performance. The presence of antinutritional bioactive compounds in C. abbreviata, even though unquantified, could be the reason of depressed $\mathrm{ADG}$ and gain to feed ratio in birds administered with 200 and $500 \mathrm{mg} / \mathrm{kg}$. Sobeh et al. (2018) found that extract from root bark of C. abbreviata contain high content of phenolics such as proanthocyanidins (also known as condensed tannins). Condensed tannins bind with and engulf protein, compromising protein availability, digestibility and utilisation and this may have an indirect bearing on ADG (Huang et al., 2018). The presence of other phytochemicals such as alkaloids, steroids, terpenoids and saponins could have a detrimental effect on the performance of birds. It can be advised that stem bark extract from C. abbreviata should at most be dosed to $50 \mathrm{mg} / \mathrm{kg}$, beyond this point, the growth performance is compromised.

Superoxide dismutase belongs to the first level of the antioxidant defence network (Surai, 2016). In addition, as important vitagene, it is the main driving force in cell or body adaptation to various stress conditions. High SOD in birds dosed with 200 and $500 \mathrm{ml} / \mathrm{kg} \mathrm{BW}$ suggest that $C$. abbreviata stem bark extract was effective in enhancing SOD activity. This also reveals in vivo antioxidant properties of $C$. abbreviata stem bark extract. This is useful for birds because increase in antioxidant activity ensures proper and rapid elimination of reactive oxygen species that could be formed under high stocking density. Therefore, administrating birds with $C$. abbreviata stem bark extract could enhance scavenging of reactive oxygen species by increasing activity of SOD. Mongalo and Mafoko (2013) alluded that the extract of stem bark exhibited IC $_{50}$ of $1.87 \pm 0.25 \mathrm{mg} / 100 \mathrm{ml}$ against 2,2-diphenyl-1-picrylhydrazyl (DPPH), which is a good scavenging characteristic of free radicals. In a separate but similar study, Wang et al. (2008) reported that Forsythia suspensa extract increased SOD levels in broiler chickens. Results that showed the lowest MDA levels in birds administered with $500 \mathrm{mg} / \mathrm{kg}$ of C. abbreviata dosage confirmed the antioxidant property of $C$. abbreviata stem bark extract. Lower levels of MDA indicate a reduction in oxidative damage (lipid peroxidation) as result of dosing birds with C. abbreviata stem bark extract.

The damage and recovery of liver is normally measured by the activity of serum transaminases such as AST and ALT (Atsafack et al., 2015). These enzymes are sensitive to toxic substances and play a crucial role in assessing pathological state of birds (Gudiso et al., 2019). Higher activity of AST and ALT birds dosed with $500 \mathrm{mg} / \mathrm{kg}$ of stem bark extract from $C$ abbreviata concur with toxicological study by Atsafack et al. (2015) who reported an increase in AST and ALT in rats dosed with stem bark extract from Schefflera barteri. Cassia abbreviata stem bark extract contains phytochemicals that may have a propensity to increase the production of liver enzymes. Judging from high activity of AST and ALT activities, it is likely that stem bark extract from C. abbreviata has a hepatotoxicity effect when dosed at higher level such as $500 \mathrm{mg} / \mathrm{kg}$.
This is also verified by liver histopathological studies, which highlighted congestions in the lymphocytic hepatitis, necrotic changes and necropurulent hepatitis. Presence of phytochemicals such as tannins and alkaloids could have had negative impact on hepatica function.

An increase in CAT levels as a result of high stocking density conflicts with the results obtained by Simsek et al. (2009) which showed no change in serum CAT in broilers housed in high stocking density. The discrepancies could be due to different breed of chickens used and stocking densities. The activity of CAT is the defence that is responsible for converting hydrogen peroxide into water and oxygen (Surai, 2016). The removal of hydrogen peroxide protects cells against oxidative damage caused by hydrogen peroxide toxicity (Deepak et al., 2015). Higher CAT activity in birds kept under high stocking density when administered with $500 \mathrm{mg} / \mathrm{kg}$ of C. abbreviata stem bark extract suggests that this plant extract was involved in synthesis of CAT, an antioxidant enzyme responsible for adaptation of birds to oxidative stress.

\section{Conclusion}

Increasing stocking density depressed growth performance and induced oxidative stress. Stocking density did not affect liver function. Surprisingly, high dose of $C$. abbreviata extract reduced growth performance. Dosage levels of $C$. abbreviata extract reduced oxidative stress. Dosage levels of C. abbreviata induced hepatotoxicity in birds. This suggests the need to gauge dosage level of $C$. abbreviata extract that will improve growth rate, minimize oxidative stress and be hepatotoxic-free in indigenous chickens.

Acknowledgements The funding for this work was provided by the University of Zululand research grant (C452-25108).

\section{Compliance with ethical standards}

Conflict of interest The authors declare that they have no conflict of interest.

Open Access This article is distributed under the terms of the Creative Commons Attribution 4.0 International License (http:// creativecommons.org/licenses/by/4.0/), which permits unrestricted use, distribution, and reproduction in any medium, provided you give appropriate credit to the original author(s) and the source, provide a link to the Creative Commons license, and indicate if changes were made.

\section{References}

Atsafack, S. S., Kuiate, J. R., Mouokeu, R. S., Mogtomo, M. L. K., Tchinda, A. T., De Dieu, T. J., Nana, H. M., Etame, R.M.E., Biyiti, L and Ngane, R. A. N., 2015. Toxicological studies of stem bark extract from Schefflera barteri Harms (Araliaceae). BMC Complementary and Alternative Medicine, 15, 44. 
Bergmeyer, H. U., Hoder, M. and Rej, R., 1986. Approved recommendation on International Federation of Clinical Chemistry methods for the measurement of catalytic concentration of enzymes. Part 2, International Federation of Clinical Chemistry method for aspartate aminotransferase. Journal of Clinical Chemistry and Clinical Biochemistry, 24, 497-510.

Cengiz, Ö., Köksal, B. H., Tatlı, O., Sevim, O., Ahsan, U., Uner, A.G., Ulutas, P.A., Beyaz, D., Büyükyörük, S., Yakan, A and Önol, A.G., 2015. Effect of dietary probiotic and high stocking density on the performance, carcass yield, gut microflora, and stress indicators of broilers. Poultry Science, 94,2395-2403.

Dawkins, M. S., 2018. "Stocking density: can we judge how much space poultry need?." In Advances in Poultry Welfare. Woodhead Publishing. pp. 227-242.

Deepak, M.K., Surendra, S.K., Mahabaleshwar, V. H and Hanhong, B.A.E., 2015. Significance of antioxidant potential of plants and its relevance to therapeutic applications. International Journal of Biological Sciences, 11, 982-991.

Dozier III, W. A., Thaxton, J. P., Purswell, J. L., Olanrewaju, H. A., Branton, S. L and Roush, W. B., 2006. Stocking density effects on male broilers grown to 1.8 kilograms of body weight. Poultry Science, 85, 344-351.

Droge, W., 2002. Aging-related changes in the thiol/disulfide redox state: implications for the use of thiol antioxidants. Experimental Gerontology, 37,1333-45.

Estevez I., 2007. Density allowances for broilers: Where to set the limits? Poultry Science, 8, 1265-1272.

Goo, D., Kim, J. H., Choi, H. S., Park, G. H., Han, G. P and Kil, D. Y., 2018. Effect of stocking density and sex on growth performance, meat quality, and intestinal barrier function in broiler chickens. Poultry science, pey491, https://doi.org/10.3382/ps/pey491

Gudiso, X., Hlatini, V., Ncobela, C., Chimonyo, M and Mafongoya, P., 2019. Serum metabolites and weights of internal organs of broilers fed on varying levels of Vachellia angustissima leaf meal. Canadian Journal of Animal Science, (ja). https://doi.org/10.1139/CJAS2018-0047.

Gwala, M.P., 2014. Contribution of village chickens to the resource-poor households. MSc dissertation. University of KwaZulu-Natal.

Harbone, J.B., 1973. Phytochemical methods: a guide to modern techniques of plant analysis. London: Chapman and Hall Ltd, pp. 116.

Huang, Q., Liu, X., Zhao, G., Hu, T and Wang, Y., 2018. Potential and challenges of tannins as an alternative to in-feed antibiotics for farm animal production. Animal Nutrition, 4, 137-150.

Joubert, J.J., 1996. The story of the indigenous domestic animals in South Africa. Agricultural Research Council, Private Bag X2, Irene, 0062. South Africa. (unpublished).

Kahkonen, M.P., Hopia, A.I., Vuorela, H. J., Rauha, J.P., Pihlaja, K., Kujala, T.S and Heinonen, M., 1999. Antioxidant activity of plant extracts containing phenolic compounds. Journal of Agricultural and Food Chemistry 47, 3954-3962.

Lin, H.S, Decuypere, E and Buyse, J., 2004. Oxidative stress induced by corticosteone administration in broiler chickens (Gallus gallus domesticus). Comparative Biochemistry and Physiology 139, 745751.

Madilindi, M. A., Mokobane, A., Letwaba, P. B., Tshilate, T. S., Banga, C. B., Rambau, M. D., Bhebhe, E and Benyi, K., 2018. Effects of sex and stocking density on the performance of broiler chickens in a sub-tropical environment. South African Journal of Animal Science, 48, 459-468.

Mongalo, N. I and Mafoko, B. J., 2013. Cassia abbreviata Oliv. A review of its ethnomedicinal uses, toxicology, photochemistry, possible propagation techniques and pharmacology. African Journal of Pharmacy and Pharmacology, 7, 2901-2906.

Moreira, J., Mendes, A. A., Roça, R. D. O., Garcia, E. A., Naas, I. D. A., Garcia, R. G., \& Paz, I. C. L. D. A., 2004. Effect of stocking density on performance, carcass yield and meat quality in broilers of different commercial strains. Revista Brasileira de Zootecnia, 33, 1506 1519 .

Mosa, E.O., Elhadi, M.A and Mahgoub, S.E., 2012. Preliminary phytochemical evaluation and seed proximate analysis of Surib (Sesbania leptocarpa DC.) Sudan Journal of Medical Sciences, 7, 29-34.

Mtileni, B. J., Nephawe, K. A., Nesamvuni, A. E and Benyi, K., 2007. The influence of stocking density on body weight, egg weight, and feed intake of adult broiler breeder hens. Poultry science, 86, 16151619

Ncobela, C. N and Chimonyo, M., 2015. Potential of using nonconventional animal protein sources for sustainable intensification of scavenging village chickens: a review. Animal Feed Science and Technology, 208, 1-11.

Odunitan-Wayas, F. A., Kolanisi, U., Chimonyo, M and Siwela, M., 2016. Effect of provitamin A biofortified maize inclusion on quality of meat from indigenous chickens. The Journal of Applied Poultry Research, 25, 581-590.

Ordonez, A.A., Gomez, J.G., Vattuone, M.A and Isla, M.I., 2006. Antioxidant activities of Sechium edule swart extracts. Food Chemistry, 97, 452-458.

Simitzis, P. E., Kalogeraki, E., Goliomytis, M., Charismiadou, M. A., Triantaphyllopoulos, K., Ayoutanti, A., Niforou, K., HagerTheodorides, A.L and Deligeorgis, S. G., 2012. Impact of stocking density on broiler growth performance, meat characteristics, behavioural components and indicators of physiological and oxidative stress. British poultry science, 53, 721-730.

Simsek, U. G., Dalkilic, B., Ciftci, M and Yuce, A., 2009. The influences of different stocking densities on some welfare indicators, lipid peroxidation (MDA) and antioxidant enzyme activities (GSH, GSH-Px, CAT) in broiler chickens. Journal of Animal and Veterinary Advances, 8, 1568-1572.

Sobeh, M., Mahmoud, M. F., Abdelfattah, M. A., Cheng, H., El-Shazly, A. M and Wink, M., 2018. A proanthocyanidin-rich extract from Cassia abbreviata exhibits antioxidant and hepatoprotective activities in vivo. Journal of ethnopharmacology, 213, 38-47.

SPSS, 2012. Statistical Package for the Social Sciences. SPSS Inc., Chicago, USA

Surai, P. F., 2016. Antioxidant systems in poultry biology: superoxide dismutase. Journal of Animal Research and Nutrition, 1, 8.

Thomas, D. G., Ravindran, V., Thomas, D. V., Camden, B. J., Cottam, Y. H., Morel, P. C. H. and Cook, C. J., 2004. Influence of stocking density on the performance, carcass characteristics and selected welfare indicators of broiler chickens. New Zealand Veterinary Journal, $52,76-81$

Tong, H. B., Lu, J., Zou, J. M., Wang, Q and Shi, S. R., 2012. Effects of stocking density on growth performance, carcass yield, and immune status of a local chicken breed. Poultry science, 91, 667-673.

Wang, L., Piao, X. L., Kim, S. W., Piao, X. S., Shen, Y. B and Lee, H. S., 2008. Effects of Forsythia suspensa extract on growth performance, nutrient digestibility, and antioxidant activities in broiler chickens under high ambient temperature. Poultry science, 87, 1287-1294.

Yun-Zhong F, Sheng Y and Guoyao W., 2002. Regulation of physiological systems by nutrients: free radicals, antioxidants, and nutrition. Nutrition 18, 872-879.

Publisher's note Springer Nature remains neutral with regard to jurisdictional claims in published maps and institutional affiliations. 